\title{
Poverty Alleviation Policies in Malaysia and Nigeria: A review
}

\author{
Zarina Mohd Zain ${ }^{1}$, Nor Suhaiza Md Khalid ${ }^{1}$, Suzei Mat Nurudin ${ }^{1}$, Timothy Onimisi ${ }^{2}$ \\ ${ }^{1}$ Faculty of Administrative Science and Policy Studies, Universiti Teknologi MARA \\ ${ }^{2}$ Department of Political Science, Federal University of Lokoja, Nigeria \\ zarina752@uitm.edu.my, suhaiza353@uitm.edu.my, suzei509@uitm.edu.my, timothy.onimisi@fulokoja.edu.ng \\ Tel: +60126458612
}

\begin{abstract}
Poverty in Malaysia and Nigeria as well as most developing countries are alarmingly visible. The Gross Domestic Product (GDP) growth in recent years of Malaysia and Nigeria has not reflected in the poverty alleviation efforts from the governments of both countries. The need to review the past policies on poverty alleviation in these developing nations prompted this paper. Using secondary data sources, the poverty alleviation policy in Malaysia has made significant progress, while Nigeria is still struggling. Interestingly, after decades of poverty alleviation policies, Malaysia has been moving forward steadily although there are identifiable challenges to overcome while in Nigeria, the policies seems to have no progress due to lack of political will.
\end{abstract}

Keywords: Poverty Alleviation; Policy; Developing Countries

eISSN: 2398-42870 2021. The Authors. Published for AMER ABRA cE-Bs by e-International Publishing House, Ltd., UK. This is an open access article under the CC BYNC-ND license (http://creativecommons.org/licenses/by-nc-nd/4.0). Peer-review under responsibility of AMER (Association of Malaysian Environment-Behaviour Researchers), ABRA (Association of Behavioural Researchers on Asians/Africans/Arabians) and CE-Bs (Centre for Environment-Behaviour Studies), Faculty of Architecture, Planning \& Surveying, Universiti Teknologi MARA, Malaysia.

DOI: https://doi.org/10.21834/ebpj.v6i16.2694

\subsection{Introduction}

The most important necessities of life such as shelter, food, clean water, education, good health will guarantee a quality of life (QoL). However, not everyone has access to these needs, such as the developing countries of Malaysia and Nigeria where some of the citizens are living in poverty. Incidence of poverty in Nigeria is chronic and on a continuous rise. The total population of the country's citizens living below the $\$ 1$ a day threshold is on the increase despite the growth of Gross Domestic Product (GDP) in recent years (Omotunde, 2014; Clement \& Dickson 2019). The ineffective implementation of the various poverty alleviation policies has hindered the investment opportunities in the social and economic sectors that would ordinarily increase the citizens' productivity. In Malaysia for instance, as far back as the 1970s, it developed its poverty line after making poverty eradication the top priority of the government's national policy and using the assessments of the minimum consumption level of an average household basic needs of life such as shelter, food, clothing and another non-food needs (Hatta \& Ali, 2013; Business Media LLC, 2021). Urban poverty rate had decreased from $4.8 \%$ in 2016 to $3.8 \%$ in 2019 and like rural areas, the rate reduced from $17.5 \%$ to $12.4 \%$. Assessing the poverty incidence among the ethnic groups in Malaysia, Bumiputera still leads by having $7.2 \%$ poverty rate followed by India $(4.8 \%)$ and Chinese $(1.4 \%)$ (Mid-term report of $11^{\text {th }}$ Malaysian Plan, 2020). Looking at the data however, the unemployment rate in Malaysia climbed to 4.8 percent in 2020 from 3.2 percent in the previous year. The number of unemployed jumped 48.7 percent to 764.4 thousand, while employment declined by 0.8 percent to 15.20 million (tradingeconomics.com, 2020). In the meantime, the labor force rose from 0.8 percent to 15.96 million and the jobless rate was at 4.7 percent (Department of Statistics in Malaysia, 2020).

eISSN: 2398-42870 2021. The Authors. Published for AMER ABRA cE-Bs by e-International Publishing House, Ltd., UK. This is an open access article under the CC BYNC-ND license (http://creativecommons.org/licenses/by-nc-nd/4.0). Peer-review under responsibility of AMER (Association of Malaysian Environment-Behaviour Researchers), ABRA (Association of Behavioural Researchers on Asians/Africans/Arabians) and cE-Bs (Centre for Environment-Behaviour Studies), Faculty of Architecture, Planning \& Surveying, Universiti Teknologi MARA, Malaysia.

DOI: https://doi.org/10.21834/ebpj.v6i16.2694 
Poverty alleviation policies in developing countries demand improvement of social security, socio-political inclusion of the people concerned, increased opportunity in socio-economic growth, better healthcare, access to education, and provision of infrastructure for quality of life (World Bank, 2001). This supports the ideas of development and global vision as stated in the Sustainable Development Goals where Goal 1 clearly promotes "no poverty" and "end poverty in all its forms everywhere" (Business Media LLC, 2021). Despite, the poverty alleviation policies put in place and being a vital instrument for the uplifting of the poor out of poverty in developing countries and an instrument of choice for legislatures for promoting their achievements, the implementation of these policies remains an issue (Business Media LLC 2021; Singh, 2020). Malaysia and Nigeria were chosen as the subjects because both countries gained their independence around the same time period. Besides, the efforts shown by the political elites toward poverty alleviation is similar as well as the objectives for the poverty alleviation policies. Despite the similarities, the progress toward poverty alleviation is not in the same direction hence the necessity for the study to be conducted.

\title{
2.0 Literature Review
}

\subsection{Conceptualization on poverty alleviation}

Various scholars define poverty according to the understanding, disciplinary approaches, influences, ideologies, and beliefs. According to Grusky and Kanbur (2006), the Western perspective defined poverty in terms of monetary value, individuals earn, using their levels of income or consumption, and those persons whose falls below certain income (often one-two dollar), consumption level are considered poor or in the state poverty. Poverty is the state of sense of helplessness, lack of opportunities, dependence, and self-confidence as well as self-respect on the part of the poor (Aiyedogbon \& Ohwofasa, 2012; Masri, Yunus, Ahmad, 2014; Yunus, Samadi, \& Omar, 2018). The United Nations (1998) statement describes thus:

\begin{abstract}
Poverty is a denial of choices and opportunities, a violation of human dignity. It means lack of basic capacity to participate effectively in society. It means not having enough to feed and clothe a family, not having a school or clinic to go to; not having the land on which to grow one's food or a job to earn one's living, not having access to credit. It means insecurity, powerlessness and exclusion of individuals, households and communities. It means susceptibility to violence, and it often implies living in marginal or fragile environments, without access to clean water or sanitation (http://www.noblenations.org, 2013).
\end{abstract}

For this study, poverty is the lack of ability, capacity, and opportunities to satisfactorily provide for oneself the basic needs of life. The multidimensional level of poverty reflected in the methodological approach used to conceptualize it as it is seen as powerlessness and voice-less-ness state (Narayan et al., 2000; Handley et al., 2009). Poverty in Malaysia and Nigeria is present in both rural and urban areas, but with a significant presence in the rural area due to numerous reasons such as lack of basic amenities of life and weak economic activities (Business Media LLC, 2021). Poverty is considered chronic when it is static. Poverty is the absence of or lack of ability to provide and access necessities of life. Bhagwati and Panagriya (2012) stated that poverty alleviation policies need economic growth to generate revenues for expansion which enables the governments to spend on healthcare, education, housing and other social amenities. According to Singh (2020:2), poverty alleviation strategies can be classified into four which are "community organizations based on micro-financing, capability and social security, market-based, and good governance" (Osabuohien, 2020).

Poverty is one of the biggest challenges confronting humanity today (Dauda, 2016). According to Cook (2013), a billion people live below US\$1.25 per day globally, with about 1.75 billion people suffering from multidimensional poverty, economic deprivation, lack of qualified education, good healthcare and low living standard. Unfortunately, the majority of the poor people are found in the developing countries of Asia and Africa. The increasing number of the poor people in the developing countries calls for concern, because other countries of the world are making progress and countries in the developing world are not. According to Gyimah-Brempong (2002), the African situation has worsened due to unequal income and wealth distribution. While countries like Malaysia are making serious efforts to bridge the gap between the rich and the poor through policies and programmes, Nigeria, one of the largest nations in Africa, is having negative policy feedback because the gap between the rich and the poor is increasing. Economic growth and development literature shows that increased income per head has a positive impact on the welfare of the poor (Dauda, 2016; World Bank, 2001). According to Dauda (2016), economic growth stimulates productive capacity of the economy and helps to increase investment drive in education, health, and employment, personal as well as national income. Economic growth does not affect the poor, but growth at the national economy level lowered poverty (ljaiya et al., 2011).

\subsection{Brief Review of Various Poverty Alleviation Policies in Malaysia and the Nigerian Government}

\subsubsection{In Malaysia}

In 2019, the absolute poverty rate of the population was at $5.6 \%$. Malaysia revised its national poverty line income, increasing it from RM980 to RM2,208. This accounted for the increases in the poverty rate in 2016 (Hirschmann, 2020). The concept of the poverty line in Malaysia was drawn based on the consumption of the citizens (Clemen \& Dickson, 2019.) The poverty status was determined based on gross household income rather than popular expenditure thus, making households income that is below the poverty line categorized as living in poverty (Zulkarnain \& Isahaque, 2013.) Earning below half of the poverty line was considered as living in extreme poverty or 
what was termed "hard-core" poverty (Hatta \& Ali, 2013). The revised poverty line version was created putting into consideration the food poverty line and meeting the basic minimum of food needed for a household.

To combat the issue of poverty in Malaysia, historically, Malaysia used the narrow 'welfare-state' style policies where public health programmes were rolled out for the people, and free education and unemployment benefits were paid (Zulkarnain \& Isahaque, 2013). In the context of alleviation of socio-economic inequalities, the government had expanded the economy and given subsidies to the needy. Government also enables equitable opportunities for all and provides social security coverage for the disadvantaged groups. Apart, impartial admittance to health, education and basic infrastructure are being accentuated (Zulkarnain \& Isahaque, 2013; Apata et al., 2010). Mechanisms for targeted income sustenance will be enhanced as general subsidies are being phased out. In addition, a succession of strong governments and a public sector committed to improve the welfare and well-being of all Malaysians helped in overcoming the issues of poverty in Malaysia (http://www.ccsenet.org, 2014).

Improved capacity building was enhanced, and new programmes were introduced in order to take care of the vulnerable societies (http://www.ccsenet.org, 2014). The ideas to advance the agricultural sector, strengthening small medium businesses, increasing home ownership, developing public health facilities and Microfinance aids were given high priority by the government to engage with poverty (Zulkarnain \& Isahaque, 2013; Hussaini, 2014). In addition, New Economic Policy was introduced in the 1970s, with objectives to support the economy with income equality and restructure the society. In making it a broader 'welfare-state', the government had introduced FELDA, FELCRA as agencies to cater poverty eradication in a rural area (Mohd, 2012). Over the period of 1981-1997, the country adopted a rigorous social policy aimed at combat poverty, with a focus on the extreme poor society, while the NGOs involvement in microcredit was hence, and the private involvement privatization and moderate government expenditure were encouraged. From 1998 to 2002, the country experienced a financial crisis, which affected the poor, and social protection plans suffered (Mohd, 2012). The government also introduced the New Economic Model (NEM) that provides the conceptual macro approach to achieving poverty eradication and income disparity reduction by promoting eight Strategies Reform Initiatives (SRI) (David, Sushil, Abid Haleem \& Zafar, 2014; Mohd Zin \& Xavier, 2015). The strategies include; 1) re-energising the private sector, 2) developing a quality workforce and reducing the dependence on foreign labour; (3) creating a competitive domestic economy; (4) strengthening the public sector; (5) transparent and market friendly affirmative action; (6) building the knowledge base and infrastructure; (7) enhancing sources of growth; and (8) ensuring the sustainability of growth (Mohd Zin \& Xavier, 2015). In addition, Malaysia's National Social Welfare had focused on Agriculture Productivity in order to achieve zero-poverty thus impacted positively on the poor citizens and helped to reduce the poor level in the country.

\subsubsection{In Nigeria:}

Poverty is widespread in Nigeria where necessities of life are seriously lacking in the country. The lack of clothing, food, education, basic amenities, and poor health service makes one begin to wonder how the citizens survive in the face of these numerous challenges. Various administrations have continuously formulated poverty alleviation policies aimed at taming this social malaise called poverty even in the face of immense natural and human resources (Aminu \& Onimisi, 2014). The Nigerian poverty alleviation programme was formally integrated into the country's development objective in the 1990s, even though the National Development Plans of 1962 to 1985 , and the National Rolling Plans of the 1990s indicated that much of the framework in the pursuit of development and poverty alleviation began since the political independence in 1960 (Aminu, Isa \& Timothy Onimisi, 2014; Obadan, 2001; https://allafrica.com). However, after the establishment Program, the citizens were worse off as the poverty level in the country began to increase. Thus, the implementation of structural adjustment programme has worsened in an existing economic condition of Nigerians during the mid-1980s and to 1900s, as the vulnerable people found life meaningless, industrial strike action became of the day, the budget deficit increased, retrenchment of workers, and inflation became obvious, and hardship became apparent in the country (Boboye \& Ojo, 2012).

The Structural Adjustment Programme (SAP) introduced by the military regime of General Ibrahim Babangida escalated poverty level among many vulnerable citizens in the society, which led the subsequent administration to come with various poverty alleviation measures such as the Poverty Alleviation Programme Development Committee (PAPDC) introduced in 1994 under the aegis of the National Planning commission (Aminu, Isa \& Timothy Onimisi, 2014; Obadan, 2001). The poverty alleviation programme tagged PAPDC was mandated to advise the government and coordinate the implementation of poverty alleviation in the country. In 1996, the then military regimen established the Community Action Programme for Poverty Alleviation CAPPA to ensure the vulnerable people for which the poverty alleviation was created are carried along in the formulation and implementation of the programmes that concern them (Aminu, Isa \& Timothy Onimisi, 2014). The various poverty alleviation policies and programmes formulated by both the military and democratic administrations between 1986 and 2004 in Nigeria were Poverty Eradication Programme (PEP), The National Poverty Eradication Programme (NAPEP) and National Directorate of Employment (NDE) (Gberevie et al., 2010). The ineffective implementation of previous poverty alleviation programmes led to the formulation of the Economic Empowerment and Development Strategy at the national, state and local government levels in the rural areas by reforming government institutions and involving the private sectors and value orientation (Aminu, Isa \& Timothy Onimisi, 2014; Shola Omotola,2008).

The post-SAP poverty alleviation programmes of the Nigerian government were the National Directorate of Employment (NDE); Community Banks program (CBN) and Better Life Program (BLP) which were implemented at one point on the other (Musa \& Abdullah, 2016). It is important to note that these policies on poverty alleviation were to a great extent received poor implementation because of lack of transparency, policy instability, lack of accountability, poor budgetary provision, and inadequate coordination (Hussaini, 2014). The fourth republic witnessed policies such as the Poverty Alleviation Programme (PAP), National Poverty Eradication Programme (NAPEP) having a structure such as Social Welfare Service Scheme (SOWESS), Youth Empowerment Scheme (YES) and Rural Infrastructure Development Scheme (RIDS) currently at the implementation stage (Musa \& Abdullah, 2016). 


\subsection{Establishing a Common Ground}

\subsubsection{Recognizes the Need to Alleviate Poverty}

The developing countries such as Malaysia and Nigeria need to alleviate poverty amongst their citizens. Both countries understand the challenges faced by the citizens of their nations especially in the area of poverty. Issues on poverty not only affect an individual but also the family and nations so it is needed for action taken by the government to hinder the issues so that people can live in harmony and the stability to achieve quality of life can be guaranteed.

\subsubsection{Recognizes the Consequences of Increasing Poverty}

Higher numbers of incidence of poverty will give bad consequences to the countries. It caused high criminal issues and will result in other social issues in society. In addition, the major concern of poverty includes patterns of economic growth and the development which is unsustainable. Lack of infrastructures, unemployment, poor basic services and income will affect the social life of the poor which has impacts on their quality of life.

\subsubsection{Made Efforts through Enactment of Poverty Alleviation Policies}

Malaysian and Nigerian governments at various times came up with policies aimed at poverty alleviation. The Malaysian experience at poverty eradication draws several policy lessons to other countries as they race to reach the millennium goal of poverty eradication and Nigeria also in track with the goals. The key implications faced by both countries include the prerequisite of strong economic growth for a sustained approach to poverty eradication and political commitment as manifested in the policies and institutions directed at poverty eradication (David, Sushil, Abid Haleem \& Zafar, 2014).

\subsection{Methodology}

This paper used existing relevant literature, documents, and articles which were later analyzed for the findings and discussion. The annual reports of the Malaysian Statistics Department and mid-term report on 11th Malaysian Plan (2016-2020), Nigeria National Development Plans and National Rolling Plans were of great assistance during the course of the study. In addition, the review includes manuals, scholarly journal articles, books, and brochures were equally subjected to analysis. Two main databases were used to search for articles which are Scopus and Web of Science, and a supporting database of Google Scholar was used to support the search. A total of 32 articles were used. Secondary source of data serves as the purpose for which the article was set out for. The analysis of findings shown in the table to compare policies and program implemented by both countries.

\subsection{Findings}

Table 1: Comparison of Malaysia and Nigeria Poverty Alleviation Policies

\begin{tabular}{|l|l|l|}
\hline Years & Malaysia & Nigeria \\
\hline $1957-1971$ & Narrow 'welfare-state' style policies & National Development Plans \\
\hline $1971-1990$ & New Economic Policy & $\begin{array}{l}\text { National Rolling Plans / Structural Adjustment Programme / Poverty } \\
\text { Alleviation Programme Development Committee (PAPDC) }\end{array}$ \\
\hline $1990-2000$ & New Development Policy & $\begin{array}{l}\text { Community Action Programme for Poverty Alleviation CAPPA / } \\
\text { Poverty Eradication Programme (PEP) }\end{array}$ \\
\hline 2001-present & $\begin{array}{l}\text { National Vision 2020 } \\
\text { New Economic Model } \\
\text { National Social Welfare }\end{array}$ & $\begin{array}{l}\text { The National Poverty Eradication Programme (NAPEP) / Social } \\
\text { (YES) and Rural Infrastructure Development Scheme (RIDS); } \\
\text { Various Social Investment Schemes (Npower etc) }\end{array}$ \\
& \multicolumn{2}{|l}{} \\
\hline
\end{tabular}

A comparative review of the Malaysia and Nigeria poverty alleviation policies shows that, the Malaysian government used the used the narrow 'welfare-state' style policies where focus centered on public health programs, free education, and unemployment benefit were rolled out for the people, and free education and unemployment benefits. This development has been translated through the promulgation of the New Economic Policy (NEP) in 1971 under Malaysia's first long-term development plan, 1971-1990 to support and strengthen the Government's effort to drive the economy towards promoting quality and inclusive growth to ensure that no one in the society will be left out in the development process. During the first half of the NEP period, agricultural policy through agrarian reform has been the major instrument in transforming rural areas and the poverty-stricken communities into a more prosperous Malaysian society. Since the majority of the poor were in the agricultural sector in rural areas, the focus of the poverty eradication strategy was on mobilizing rural resources through land development programmes and reorganizing institutions towards modernizing and developing the agriculture and rural sector FELDA, FELCRA, IADP, land reforms and poverty reduction in the rural area of the country (Zulkarnain \& Isahaque, 2013). In the second half of the NEP period, Malaysia had transformed the economy from agricultural based to manufacturing based. 
Though agriculture was the dominant sector in the Malaysian economy throughout the 1970s, Malaysia has successfully diversified and transformed the economy from being 7 agriculturally dependent to a manufacturing based economy in the second half of the NEP period. In 1990 to 2000, during this period, Malaysia has moved into the third stage of economic development with stronger role of the manufacturing and services sectors. These sectors were the major drivers to the Malaysian economy and provide vast employment opportunities to the rakyat. The subsequent NDP had also introduced new thrusts entailing shifting the focus of the antipoverty strategy towards the eradication of hard core poverty, while the NVP incorporates the strategies to address pockets of poverty in remote areas and among Bumiputera minorities in the states of Sabah and Sarawak on the island of Borneo as well as increasing the income and quality of life of those in the lowest 30 per cent income category. The government efforts continue till present with the inclusive development approach ensure that no one is left out in contributing to and sharing in the development outcome. While perfect equality is in reality impossible to achieve in an open, global economy, an inclusive society will ensure that inequalities can be narrowed through capacity enhancement and empowerment programmes through specific strategies, include uplifting the bottom $40 \%$ household towards the creation of more prosperous and bigger middle-class society.

The Nigerian government was concerned about the National Development Plans, which was the general approach to poverty reduction and meeting the various development needs of the nations. Between 1981 and 1997, Malaysia mainly focused on poverty alleviation which involved the adoption of Rigorous Social Policies such private sector involvement and the inclusion of the NGOs as well as microcredit schemes (Zulkarnain \& Isahaque, 2013) to combat poverty in the country. Back in Nigeria during the same period, the Nigerian government had adopted the National Rolling Plans / Structural Adjustment Programme / Poverty Alleviation Programme Development Committee (PAPDC), a programme which led to high vulnerability of people, various industrial strike actions, the budget deficit increased and retrenchment of workers making the citizen worst-off. Between 1998 and 2002, the Malaysia government saw financial crisis, which impacted on various social programmes and plans of the government, during this period the Nigerian government adopted policies such as Community Action Programme for Poverty Alleviation CAPPA and Poverty Eradication Programme (PEP) to assist the most vulnerable citizens. Between 2003 and now, the Malaysian government has rigorously focused on National Social Welfare, Ministry of Women, Family, and development and agricultural productivity with a poverty target which seems to be effective in the reduction of poverty in the county (Zulkarnain \& Isahaque, 2013. During the same period, the Nigerian government focus on the National Poverty Eradication Programme (NAPEP) / Social Welfare Service Scheme (SOWESS), Youth Empowerment Scheme (YES) and Rural Infrastructure Development Scheme (RIDS); Various Social Investment Schemes (Npower etc). These programs are still ongoing and its effectiveness has not been apparent as the poverty rate keeps on increasing in the country.

Poverty reduction strategies must include the distributive elements and high levels of comprehensiveness. This can be achieved by encouraging human capital development. Public policy should go ahead in building people's capacities and capabilities to meet the opportunities in order to fulfill the demand and supply of human capital (Kubiat Umana, 2018). To reduce the number of poverty and increase the quality of life, it requires continuous economic growth. However, the extent of poverty reduction would depend on the degree to which the poor participate in the growth process and share in its proceeds (https://researchcyber.com, 2020). Improvements in human, physical and social capital of the poor are key fundamentals to increasing their ability to participate in growth. Both the rate and shape of growth make a difference for poverty reduction and the challenge is to combine growth-promoting policies with the right policies for assuring that the poor fully participate in economic development (Kubiat Umana, 2018; https://researchcyber.com, 2020).

\subsection{Discussion}

\subsection{Examining the Common Factors that hinder the implementation of Poverty Alleviation Policies}

\subsubsection{Rural and Urban Migration Challenge}

People who migrate from rural to urban areas for one reason or the other also become a challenge to the implementation of poverty alleviation policies in developing countries, especially Malaysia and Nigeria. The migration of the rural people who are categorized to be living below the poverty line or in most cases is considered as living in extreme poverty desires to move to the urban area the implementation of government policies on alleviation of poverty targeted at them becomes difficult due to their movement (Nair, 2010). Significant movement of the citizen to the urban area has created other challenges such as meeting the demands on infrastructures, job opportunities, houses with a high cost of accommodation, transportation, social and economic cost, and increase in criminal activities (Elhadary \& Samat, 2012). Urbanization if not managed would eventually lead to an increase in the poverty level and would burden unemployment, stresses the existing social infrastructure, and distorts planning thus making certain policies unattainable.

\subsubsection{Corruption}

Corruption affects the effective implementation of poverty alleviation policies especially in developing countries. Nigeria, for instance, the political elite tends to be more concerned about what they gain from every policy and programme of the government thus constituting a big challenge to the implementation of policies that would benefit fewer privileged and poor citizens across every state of the federation. This dishonesty and incompetence behavior affect the quality of policy at formulation stage (Ugwuanyi \& Emma, 2013). Indeed, most policy making objectives are subordinated to the personal rewards and interests of the political leaders and their colleagues with the result that a policy is judged more on its political merits. For these, most policies are either inappropriate or lacking well-defined objectives and programmes for their effective implementation caused policies or programmes are chaotically implemented and even sometimes 
abandoned or halted midway because the basis for formulating the policy was not predicated the existing data or need (Ugwuanyi \& Emma, 2013: http://singaporeanjbem.com)

\subsubsection{Political and Policy Instability}

The frequent change of policy alleviation programme and the inconsistent implementation, inadequate coordination, duplication of efforts, inefficient use of limited resources, and limited budgetary allocation reminds big challenges to poverty alleviation in developing countries. Some policies tend to be over ambitions, sweeping and overly fundamental in nature (Mankinde, 2005; Ugwuanyi \& Emma, 2013; http://singaporeanjbem.com). Usually, the legislature formulates policies, control and directs the implementation activities of the policy. This situation is not proper as such control and directive are mostly motivated by political interests (http://singaporeanjbem.com). The bureaucracy also cannot implement the policies effectively and meaningfully contribute to national development if it is restricted, controlled and directed by political authorities (Ugwuanyi \& Emma, 2013;:'http://singaporeanjbem.com). When there is political control and the bureaucrats are not allowed to take decisions or actions on basic routine administrative matters without consultation and the consent of relevant political authorities, it may affect the policy implementation; hence, much time and energy are wasted.

\subsubsection{Lack of Inclusion}

The limited involvement of beneficiaries of poverty alleviation schemes in the formulation and implementation of programmes has significantly affected the implementation process. The lack of inclusion of beneficiaries in the initial formulation of the programme creates a seemingly lack of motivation (Onimisi, 2014). There is also a lack of abilities and efforts where individuals themselves are to be blamed for poverty. An effective financial inclusion policy impacted the economy as it contributes to the reduction of poverty, pro-poor growth and accelerated economic growth (Olaoluwa, 2015). Levine (2005) mentioned that institutional infrastructure of the financial system contributes to reducing financial information asymmetry, contraction in transaction costs, which in return reduce poverty and increase the level of economic growth (Ogunsakin \& Fawehinmi, 2017). Nwanko (2014) found causality between access to a range of appropriate and affordable financial services and improvement in poor people's welfare and income.

\subsection{Conclusion}

This paper discussed the poverty alleviation policies in developing countries of Malaysia and Nigeria by examining the programmes implemented by the previous government in both countries. The Malaysian and Nigerian governments have invested enormous resources to combat poverty but it remains prominent in both nations. Poverty alleviation policies in Malaysia have been a success to some reasonable extent, however, more needs to be done to mitigate the challenges faced in the implementation of the policies. The Malaysian social policies are focused on inclusiveness in ensuring equitable opportunities for all citizens. The Malaysian social policy is different from Nigeria and other developing countries because of its orderly and incremental development to thrive in a stable environment, supportive government and the political will of the successive government towards improving the well-being of the citizens (Hatta \& Ali, 2013). This paper recommends the re-commitment of the government of Malaysia and Nigeria towards poverty alleviation. The political will of the government towards policy alleviation must be sustained by both governments. The poverty alleviation policies of the Malaysian and Nigerian governments must always be subjected to review in order to make the changes demanded by society. Efforts aimed at the implementation of poverty alleviation must be re-doubled, especially, in Nigeria as it has not significantly made progress. Malaysia and Nigeria, as well as other developing countries need to adopt an inclusive poverty alleviation policy where the daily operation of the programmes is handled by the community and key stakeholders.

\section{Acknowledgments}

This study was supported by the FSPPP Research Grant Collaboration (FRGC), Faculty of Administrative Science and Policy Studies, Universiti Teknologi Mara, Malaysia (project code:600-ICAEN/FRCG-01/2021). The appraisal was carried out by the Department of Political Science, Federal University Lokoja, Nigeria, and the Economic Planning Unit of Malaysia. The authors appreciate the valuable comments.

\section{Paper Contribution to Related Field of Study}

This study contributes a comprehensive analysis of the working of poverty alleviation policies for developing countries especially in Malaysia and Nigeria. This paper also increases the awareness of people as well as the government on the challenges of poverty alleviation policies in both Malaysia and Nigeria. Through the findings, the government can start to plan on the strategies that can ensure and improve the poverty alleviation policies of both Malaysia and Nigeria.

\section{References}

Aiyedogbon, O. J and Ohwofasa, O. B. (2012). Poverty and youth unemployment in Nigeria, 1987-2011. International Journal of Business and Social Science Vol. 3 No. 20. 
Apata, T.G., Apata, O.M., Igbalajobi, O.A. and Awoniyi, S.M.O. (2010). Determinants of Rural Poverty in Nigeria: Evidence from Small Holder Farmers in South-Western, Nigeriall.Journal of Science and Technology Education Research Vol. 1(4), pp. $85-91$.

Bhagwati, J. \& Panagariya, A. (2012). Reforms and economic transformation in India. Series: Studies in Indian Economic Policies. New York: Oxford University Press.

Boboye, Lawrence, \& Ojo, Michael. (2012). Effect of external debt on economic growth and development of Nigeria. International Journal of Business and Social Science $3(12)$.

Clement E.D. \& Dickson D.A. (2019). Dynamics of inequality, poverty and sustainable development of Delta State, Nigeria. GeoJournal.

Cook, S. (2011). Combating poverty and inequality: The role of social protection. Paper presented at United Nations Research Institute for Social Development, 49th Session of Commission for Social Development, New York

David, M., Sushil, Abid H. \& Zafar U. A. (2014). Advances in Global Business Research. Vol. 11, No. 1. Proceedings of the 11 th Annual World Congress of the Academy for Global Business Advancement (AGBA).

Decent Work and Economic Growth. (2021). Springer Science and Business Media LLC.

Departments of Statistics Malaysia. (2011). Monthly statistical bulletin. Retrieved from http://www.statistics.gov.my

Elhadary, Y.A.E. and N. Samat. (2012). Political economy and urban poverty in the developing countries: Lessons learned from Sudan and Malaysia. J. Geogr. Geol., 4: 212-223.

Gyimah-Brempong, K. (2002). Corruption, economic growth, and income inequality in Africa. Economics of Governance, 3(3), 183-209.

Grusky, D. and Kanbur, R. (2006). Introduction: The conceptual foundations of poverty and inequality measurement, in Grusky, D. and Kanbur, R. (eds.), Poverty and Inequality.Stanford: Stanford University Press.

Handley, G., Higgins, K. Sharma, B., Bird, K. and Cammack, D. (2009). Poverty and poverty reduction in Sub-Saharan Africa: An overview of key issues. Overseas Development Institute (ODI).

Hatta, Z. A., \& Ali, I. (2013). Poverty reduction policies in Malaysia: Trends, strategies and challenges. Asian Culture and History, 5(2), 48.

Hussaini, Mustapha. (2014). Poverty alleviation programs in Nigeria: Issues and challenges. International Journal of Development Research, Vol. 4, (3,). (717-720)

Kubiat Umana. (2018). Policy challenges towards poverty reduction in Nigeria. Retrieved from ResearchCyber.com

Levine, P. (2005). Finance and Growth: Theory, Mechanisms and Evidence, in Aghion. Handbook of Economic Growth Elsevier.

Makinde, T. (2005). Problems of policy implementation in developing nations. Journal of Social Sciences, 11(1) Pp $63-69$.

Masri, M., Yunus, R.M., Ahmad, S.S. (2014). Creating cultural innovation: Towards a holistic approach in shaping a sustainable future. ASIA Pacific International Conference on Environment-Behavioural Studies (AicE-Bs 2014Berlin), Berlin, 24-26 Feb. 2014.

Mohd, S. (2012). Welfare regime, social protection and poverty reduction. In B. T. Khoo (eds.). Policy regimes and the political economy of poverty reduction in Malaysia (pp. 107-145). UK: Palgrave Macmillan.

Mohd Zin, M \& Xavier, J.A. (2015). Poverty alleviation strategies and new economic model in Malaysia: International Academic Research Journal of Economics and Finance. Vol. No. 3 pp 17-31.

Musa, F. U \& Abdullah, A. I. L. (2016). Politics of poverty alleviation programs in Nigeria: Challenges and prospects. Journal of Education and Social Sciences, Vol. 4, (June)

Narayan, D., Chambers, R., Shah, M.K. and Petesch, P. (2000). Voices of the poor: Crying out for change. Washington D.C. World Bank.

Noble Missions. (2013). Our voice our Future. Noble Missions for Change Initiative Issue. 12-01. Retrieved from http://noblemissions.org

Nwanko, O. (2014). Sustainability of financial inclusion to rural dwellers in Nigeria: Problem and way forward. Research Journal of Finance and Accounting vol.(5) pp 80 87 .

Obadan, M. I. (2001). Poverty reduction in Nigeria: The Way Forward. Retrieved from http://mustaphamuktar.blogspot.com/2011/01/poverty-alleviationas-machineryfor.html

Ogunsakin,S. \& Fawehinmi, F.O. (2017). Financial inclusion as an effective policy tool of poverty alleviation: A case of Ekiti State. IOSR Journal of Economic and Finance. Vol. 8, Issue 4, Ver.II.

Olaoluwa A.K (2015). Effects of financial inclusion of the economic growth of Nigeria. International Journal of Business and Management Review. Vol 3, No 8, pp 11-28. Onah, R.C. (2005) Public Administration. Nsukka: Great AP Publishers

Onimisi, T. (2014). The prognoses of the 2011 electoral violence in Nigeria and the lessons for the future. Mediterranean Journal of Social Sciences Vol. 6 No. 1. Pp 242245

Osabuohien, Evans S. (2020). The Palgrave Handbook of Agricultural and Rural Development in Africa. 
Rasaki Stephen Dauda (2016): Poverty and Economic Growth in Nigeria: Issues and Policies Journal of Poverty, DOI: 10.1080/10875549.2016.1141383

Rabiul, I., Ahmad Bashawir, A.G., Irwansyah, Z. A. \& Jeya Malar, R. (2017). Impact on poverty and income inequality in Malaysia's economic growth: Journal of Problems and perspective in management. Vol. 15, Issue 1.

J. Shola Omotola.(2008). Combating poverty for sustainable human development in Nigeria: The continuing struggle. Journal of Poverty.

Singh, P. K., \& Chudasama, H. (2020). Evaluating poverty alleviation strategies in a developing country. PloS one, 15(1), e0227176.

Trading Economics. (2020). Malaysia unemployment rate 1998-2020. Retrieve from https://tradingeconomics.com/malaysia/unemployment-rate

Ugwuanyi, B.I. \& Emma, E.D. (2013). The obstacles to effective policy implementation by the public bureaucracy in developing nations: The case of Nigeria. Kuwait Chapter of Arabian Journal of Business and Management Review. Vol. 2, No. 7.

United Nations Statement of June 1998, which was signed by the heads of all UN agencies. Retrieved from : http://wwww.helium.com/items/1587576-poor-servicedelivery.

World Bank (2001). World Development Report 2000/2001: Attacking Poverty. World Development Report. Oxford University Press. New York, Washington, DC, USA. 2001.

Yakubu O. D. and Aderonmu, J.A. (2010), Rural poverty alleviation and democracy in Nigeria's fourth republic (1999-2009). In Journal of Social Sciences 2 (3), 191-195 Yuheng, L., Baozhong, S. \& Yansui, L. (2016). Realizing targeted poverty alleviation in China: People's voices, implementation challenges and policy implications.

Yunus, R. M., Samadi, Z., \& Omar, D. (2018). Community's Participation: A strategic approach in revitalizing heritage streets. Journal of ASIAN Behavioural Studies, 3(10), 29-37.

Zulkarnain, A. H. \& Isahaque, A. (2013). Poverty reduction policies in Malaysia: Trends, strategies and challenges. Journal of Asian Culture and History. Vol.5, No. 2:2013. 